\title{
Proliferation of granulosa and thecal cells in germinal disc and non-disc regions during follicular growth in Japanese quail (Coturnix coturnix japonica): bromodeoxyuridine incorporation in situ
}

\author{
Y. Yoshimura ${ }^{1}$, T. Okamoto ${ }^{2}$ and T. Tamura ${ }^{2}$ \\ ${ }^{1}$ Graduate School for International Development and Cooperation, ${ }^{2}$ Faculty of Applied Biological Science, \\ Hiroshima University, Higashi-Hiroshima 739, Japan
}

\begin{abstract}
Proliferation of granulosa and thecal cells was analysed during ovarian follicular growth in laying Japanese quail. The birds were injected intraperitoneally with bromodeoxyuridine (BrdU) 10 or $4 \mathrm{~h}$ before ovulation, that is, before or after a preovulatory LH surge, respectively, and incorporation of BrdU by follicular tissues was detected immunocytochemically. Cells labelled with BrdU were seldom seen in the most immature follicles in the ovarian cortex, whereas many granulosa and thecal cells were labelled with BrdU in medium-sized white yolky follicles (approximately $13.3 \%$ and $14.4 \%$ in granulosa and theca layers, respectively). Ten and four hours before ovulation, the granulosa cells in the germinal disc and non-disc regions of the third largest yellow yolky follicle (F3) were labelled with BrdU (approximately $8.4 \%$ and $9.4 \%$ in germinal disc; $6.1 \%$ and $9.0 \%$ in the non-disc region), but only those in the germinal disc region were labelled (approximately $5.4 \%$ and $4.0 \%$ ) in the largest yellow yolky follicle (FI). The percentage of thecal cells labelled with BrdU $4 \mathrm{~h}$ before ovulation was significantly higher than the percentage labelled $10 \mathrm{~h}$ before ovulation, and was higher in F3 (approximately 11.7\%) than in F1 follicles (approximately 5.4\%) $4 \mathrm{~h}$ before ovulation. These results show that proliferation of granulosa and thecal cells occurs in both germinal disc and non-disc regions in growing follicles, but when a follicle matures proliferation is reduced and in the case of granulosa cells it is restricted to the germinal disc region.
\end{abstract}

\section{Introduction}

The avian ovary contains numerous small non-yolky cortical follicles embedded in the ovarian stroma, and small white and large yellow preovulatory follicles. The follicular wall surrounding the oocyte consists of the granulosa and thecal layers. The germinal disc, which is believed to be a centre for oocyte growth (Yoshimura et al., 1994; Yoshimura and Bahr, 1995), is localized on the surface region of the oocyte (Yoshimura et al, 1993a). The number of granulosa cells increases approximately fivefold during the rapid growth phase of preovulatory follicles in domestic hens (Gilbert et al., 1980). The rate of proliferation of thecal cells increases as the cortical follicle develops into a white yolky follicle, and continues at a high rate during yellow-yolky follicular growth, but decreases during the final stage of follicular maturation (Callebaut et al., 1990).

The primary factors that control follicular growth are plasma gonadotrophins (Palmer and Bahr, 1989), although growth factors are also involved in the local regulation of cell proliferation (Onagbesan et al., 1994; Law et al., 1995). A study using electron microscopy shows that mitosis of granulosa cells is more frequent in the germinal disc region than in the

Revised manuscript received 26 January 1996. non-disc region (Perry et al., 1978a). In support of this observation, flow cytometric analysis and $\left[{ }^{3} \mathrm{H}\right]$ thymidine incorporation studies show that granulosa cells isolated from the germinal disc region proliferate more than do those isolated from the non-disc region (Marrone et al., 1990; Tilly et al., 1992). A role for the germinal disc region in follicular growth has also been demonstrated by studies showing that destruction of the germinal disc region results in the induction of atresia (Jackson et al., 1993; Yoshimura et al., 1994; Yoshimura and Bahr, 1995). Therefore, in addition to gonadotrophins, communications between cells in germinal disc and nongerminal disc regions appear to play an important role in the control of follicular cell proliferation.

Although previous studies have investigated factors controlling the proliferation of follicular cells, most of them have used isolated granulosa cells. Callebaut et al. (1990) investigated cell mitosis in growing follicles using autoradiography, but they did not report on differences between germinal disc and non-disc regions. Therefore, more detailed studies on the in situ proliferation of granulosa and thecal cells during follicular growth are needed to clarify the mechanism of follicular growth. Our goal was to determine the mechanism by which cell proliferation is controlled during follicular growth. In this study the proliferation of granulosa and thecal cells of quails 
were quantified in situ by use of bromodeoxyuridine (BrdU) to investigate the significance of the germinal disc region in ovarian follicular development.

\section{Materials and Methods}

Female Japanese quails (Coturnix coturnix japonica), regularly laying six or more eggs in a sequence, were kept in individual cages under a photoperiod of $14 \mathrm{~h}$ light: $10 \mathrm{~h}$ dark and provided with food and water ad libitum.

The birds were injected i.p. with BrdU (Yamasa Co., Chiba; $40 \mathrm{mg} \mathrm{kg}^{-1}$ body mass) dissolved in saline, 10 or $4 \mathrm{~h}$ before the expected time of ovulation, that is, before or after an $\mathrm{LH}$ surge, respectively (Doi et al, 1980). They were killed by decapitation, and the largest (F1) and third largest follicles (F3), white follicles (approximately $2-3 \mathrm{~mm}$ in diameter), and ovarian stroma containing cortical follicles were removed $1 \mathrm{~h}$ after BrdU injection. The surface of follicles was covered with OCT compound (Miles Inc., IN) and snap-frozen in isopentane-dry ice mixture. Cryostat sections $(10 \mu \mathrm{m})$ were air dried on slides, and fixed by sequential exposure to ice-cold paraformaldehyde-picric acid (15 min), methanol (10 min) and acetone (10 $\mathrm{min}$ ), followed by washing in PBS for $15 \mathrm{~min}$ $(3 \times 5 \mathrm{~min})$.

The incorporated BrdU was detected as described by Soriano and Del Rio (1991). First, the sections were incubated with $2.5 \mu \mathrm{g}$ proteinase $\mathrm{K} \mathrm{ml}^{-1}$ dissolved in $0.02 \mathrm{~mol}$ Tris- $\mathrm{HCl} \mathrm{l}{ }^{-1}$ buffer ( $\mathrm{pH} \mathrm{7.4)}$ ) at $37^{\circ} \mathrm{C}$ for $10 \mathrm{~min}$. After a brief rinsing with PBS, sections were treated with $0.1 \mathrm{~mol} \mathrm{HCl} \mathrm{l}^{-1}$ at room temperature for $10 \mathrm{~min}$, and then incubated with $2 \mathrm{~mol} \mathrm{HCl} \mathrm{l}^{-1}$ at $37^{\circ} \mathrm{C}$ for $20 \mathrm{~min}$. After washing with PBS for $15 \mathrm{~min}(3 \times 5 \mathrm{~min})$, the sections were incubated with $1 \%(\mathrm{w} / \mathrm{v}) \mathrm{BSA}$ in PBS for $15 \mathrm{~min}$. They were then incubated with mouse anti-BrdU monoclonal antibody (Sanbio, Uden) diluted to 1:10 in PBS for $2 \mathrm{~h}$, followed by washing with PBS for $15 \mathrm{~min}(3 \times 5 \mathrm{~min})$. The primary antibody was detected using a Vectastain ABC-PO kit (Vector Lab. Inc., Burlingame, CA) following the supplier's instructions, with $3^{\prime}, 3$-diaminobenzidine-4 $\mathrm{HCl}$ as substrate. After washing with water, sections were counterstained with haematoxylin. Specificity for BrdU was demonstrated using control sections prepared in the same manner except that the primary antibody was replaced by normal mouse $\operatorname{lgG}\left(20 \mu \mathrm{g} \mathrm{ml}^{-1}\right.$ in PBS). No nuclear staining was seen in control sections, showing that immunolabelling for BrdU was specific.

Follicles were taken from groups of five birds either $4 \mathrm{~h}$ or $10 \mathrm{~h}$ before ovulation. The number of cells labelled with BrdU and the total number of cells were counted on colour photographs. The number of cells was counted in $0.4 \mathrm{~mm}$ wide sections of granulosa and thecal layers and parallel to the surface of a follicle. The total numbers of cells counted in a photograph were approximately $60-100$ and $160-220$ in granulosa and thecal layers, respectively. The ratio of the number of labelled cells to the total number of cells in each follicle was calculated from the average counts made in two different photographs from each follicle. Values were expressed as the mean \pm SEM for five follicles. Statistical comparisons among groups were made by Duncan's multiple range test, and statistical significance was taken as $P<0.05$.

\section{Results}

The labelling of cells with BrdU in either cortical or whiteyellow follicles was similar $4 \mathrm{~h}$ and $10 \mathrm{~h}$ before ovulation. Only a few fibroblasts surrounding the granulosa layer and a few granulosa cells were labelled with BrdU in cortical follicles (Fig. Ia). In the white follicles protruding from the ovarian surface, $13.3 \pm 3.3 \%$ of granulosa and $14.4 \pm 2.9 \%$ of thecal cells were labelled with BrdU (Fig. Ib).

In F3 follicles $10 \mathrm{~h}$ before ovulation, $8.4 \%$ and $6.1 \%$ of granulosa cells were labelled with $\mathrm{BrdU}$ in the germinal disc and non-disc regions, respectively (Figs Ic, d and 2a). In FI follicles $10 \mathrm{~h}$ before ovulation, $5.4 \%$ of the granulosa cells in the germinal disc region were labelled with BrdU, whereas no labelled granulosa cells were observed in the non-disc region (Figs Ie, $f$ and $2 a$ ). In F3 follicles $4 \mathrm{~h}$ before ovulation, approximately $9 \%$ of granulosa cells of both germinal disc and non-disc regions were labelled with BrdU. In F1 follicles $4 \mathrm{~h}$ before ovulation, $4.0 \%$ of granulosa cells incorporated BrdU into the germinal disc region but no labelled cells were seen in the non-disc region (Fig. 2 b). The differences in the populations of labelled granulosa cells between $10 \mathrm{~h}$ and $4 \mathrm{~h}$ before ovulation were not significant in either FI or F3 follicles.

There was no significant difference between the percentage of BrdU-labelled thecal cells in the germinal disc and non-disc regions (Figs $1 \mathrm{c}-\mathrm{f}$ and $2 \mathrm{c}$ ). However, the percentage of labelled thecal cells in F3 follicles was higher than in FI follicles $4 \mathrm{~h}$ before ovulation $(P<0.05)$. The percentage of labelled thecal cells in FI and F3 follicles was greater at $4 \mathrm{~h}$ than at $10 \mathrm{~h}$ before ovulation $(P<0.05)$.

\section{Discussion}

The observation that cells labelled with BrdU were seldom seen in cortical follicles, but were more abundant in granulosa and thecal cells of white follicles supports the view (Callebaut $e t$ al., 1990) that granulosa and thecal cells proliferate when cortical follicles develop into white follicles. This proliferation of follicular cells may occur in association with cell differentiation, since during the transition of cortical to white follicles, androgen and oestrogen receptors appear in granulosa and thecal interstitial cells (Yoshimura et al., 1993b, 1995) and in association with the development of steroidogenic cells containing P450 aromatase (Nitta et al., 1991).

Earlier studies suggested that the germinal disc region is the growth centre for the granulosa layer (Perry et al., 1978a; Marrone et al., 1990; Tilly et al., 1992). However, in the present study there was no difference in the incorporation of BrdU by granulosa cells in germinal disc and non-disc regions in the F3 follicles. The view that the germinal disc region is a centre for the growth of the granulosa layer therefore requires re-evaluation. It seems that a factor(s) present in the germinal disc region which specifically stimulates the granulosa cell proliferation is not exclusively involved in the growth of the granulosa layer. We assume that gonadotrophins and growth factors stimulate growth of the granulosa layer in both germinal disc and non-disc regions in growing follicles, because proliferation of cultured chicken granulosa cells is stimulated by FSH and LH (Yoshimura and Tamura, 1988), cAMP 

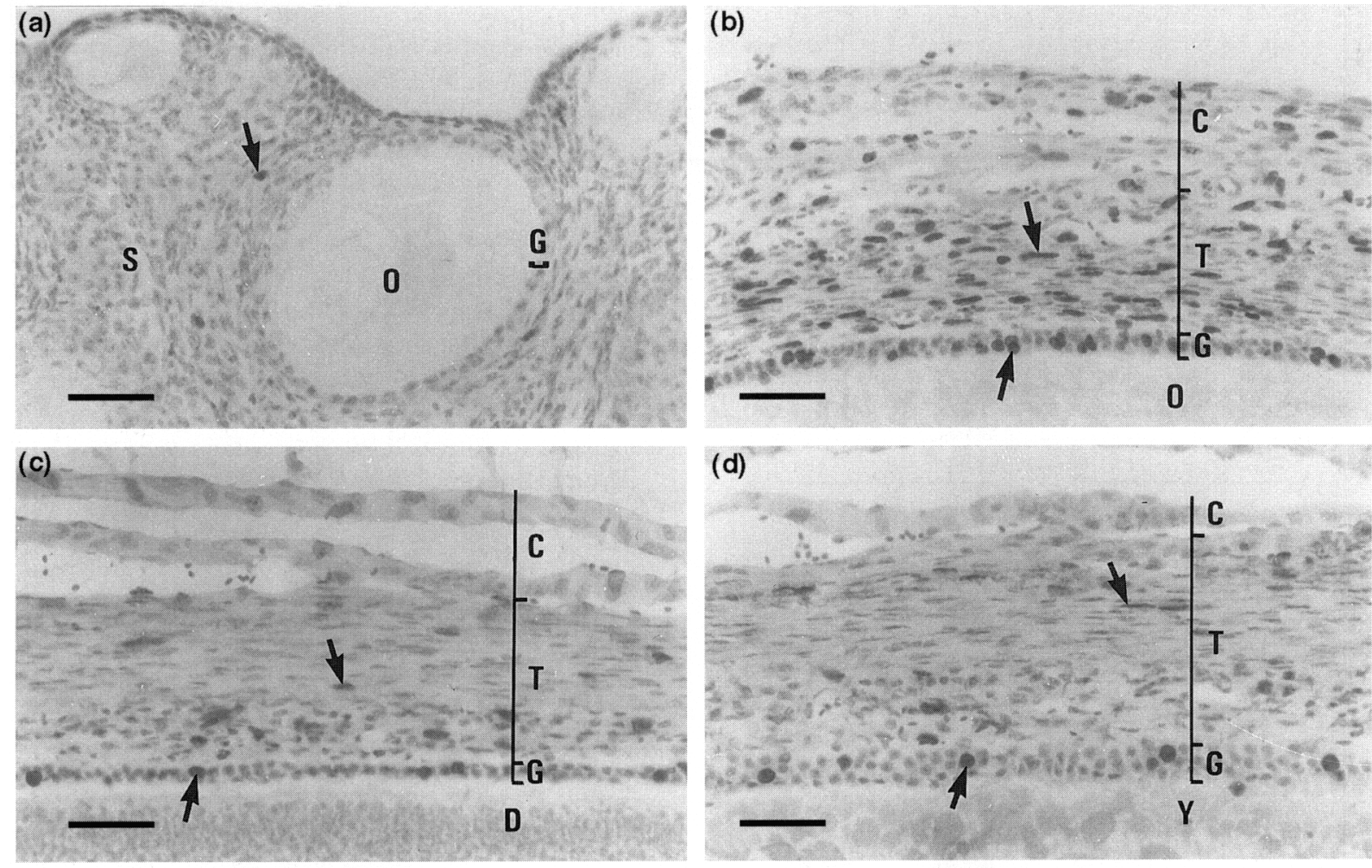

(e)

(f)
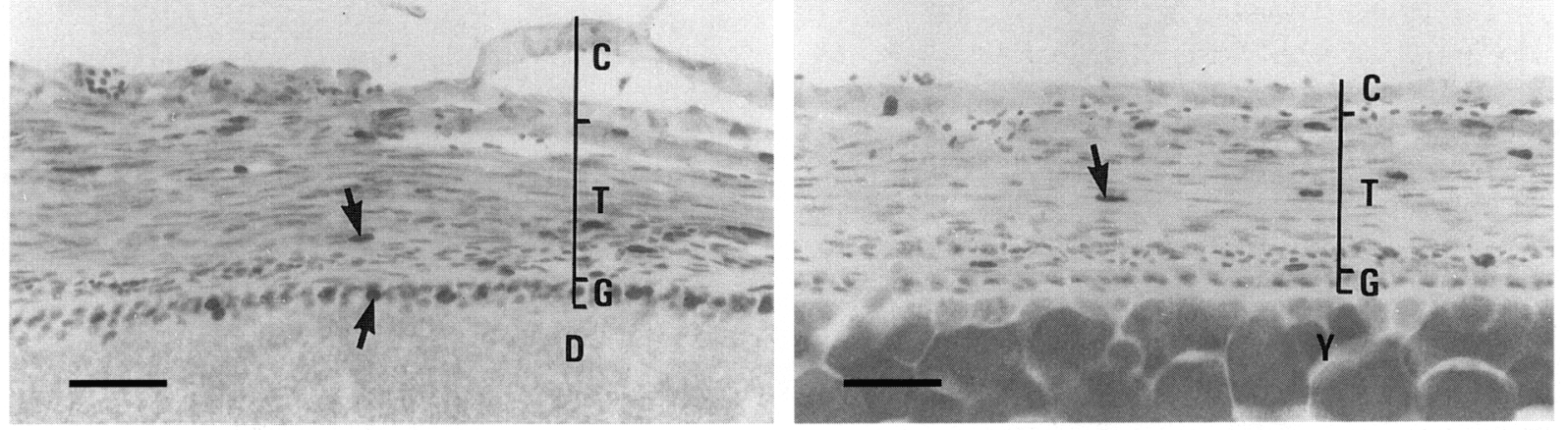

Fig. 1. Bromodeoxyuridine labelling in laying quail $10 \mathrm{~h}$ before ovulation in (a) cortical follicles in the ovarian stroma showing that only a few cells are labelled. (b) A white follicle showing numerous labelled cells in the granulosa and thecal layers. (c) and (d) The third largest follicle (F3) showing labelling in granulosa and thecal layers in both germinal disc (c) and non-disc regions (d). (e) and (f) The largest follicle (FI) showing that (e) granulosa and thecal cells are labelled in germinal disc, whereas (f) only thecal cells are labelled in the non-disc. Arrows show examples of labelled cells. C: loose connective tissue coat; D: germinal disc; G: granulosa layer; O: oocyte; S: ovarian stroma; T: thecal layer; Y: yolk. Sections were counterstained with haematoxylin. Scale bar represents $40 \mu \mathrm{m}$.

(Yoshimura and Tamura, 1991) and epidermal growth factor (Yoshimura and Tamura, 1988; Peddie et al., 1994). However, the precise mechanism by which gonadotrophins regulate the proliferation of granulosa cells remains unknown because we did not find any significant difference in BrdU incorporation by granulosa cells from follicles removed before and after the preovulatory $\mathrm{LH}$ surge ( $10 \mathrm{~h}$ and $4 \mathrm{~h}$ before ovulation, respectively).

Differentiation of granulosa cells during follicular maturation is marked by an increase in sensitivity to $\mathrm{LH}$, and the capacity to synthesize progesterone (Calvo et al., 1981; Bahr et al., 1983), loss of oestrogen receptors and an increase in progesterone receptors (Yoshimura and Bahr, 1991; Yoshimura et al., 1995). There is therefore a correlation between differentiation and cessation of proliferation of granulosa cells in the non-disc region of the FI follicle. However, this is not the case for granulosa cells in the germinal disc region in the FI follicle since they were labelled with $\mathrm{BrdU}$. We assume that the germinal disc region in the FI follicle contains some factor(s) which suppresses granulosa cell differentiation or stimulates granulosa cell proliferation. The source of such factor(s) may be the germinal disc of the oocyte, which exerts paracrine effects on the granulosa cells. In mammals, it has been reported that the oocyte provides granulosa cells with some growth factorlike signals (Buccione et al., 1990; Vanderhyden et al., 1990, 1992). 

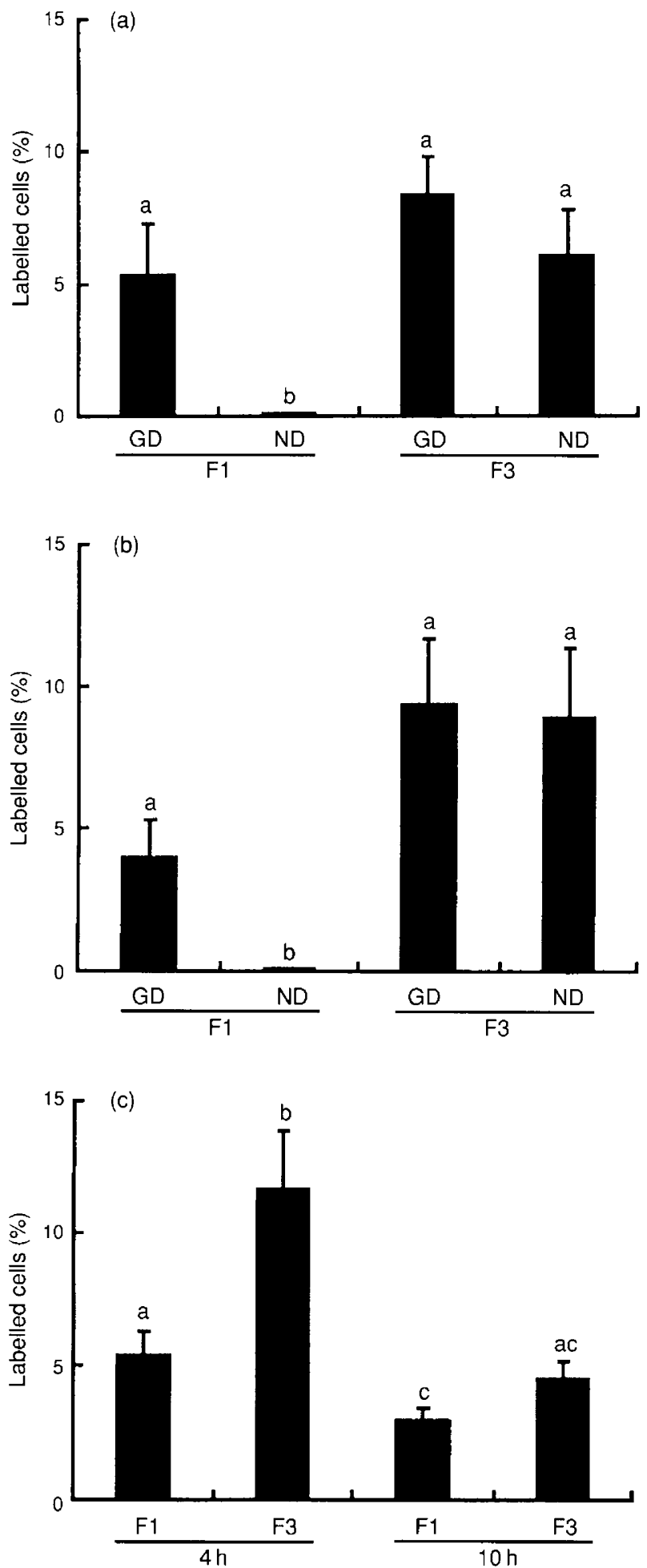

Fig. 2. Percentage of (a) and (b) granulosa and (c) thecal cells labelled with bromodeoxyuridine in the largest (F1) and third largest (F3) follicles of laying quails. Bromodeoxyuridine was administered (a) $10 \mathrm{~h}$ before ovulation; (b) $4 \mathrm{~h}$ before ovulation and (c) $4 \mathrm{~h}$ and $10 \mathrm{~h}$ before ovulation. No granulosa cells were labelled in the non-disc region in F1 follicle. GD: germinal disc region; ND: non-disc region. Each value shows the mean \pm SEM of the labelled cell population $(n=5)$. Values with different letters are significantly different $(P<0.05)$.
Although granulosa cells in the non-disc region of the F1 follicle were not labelled with BrdU, in culture they proliferate in a similar manner to the corresponding cells from the F3 follicle (Yoshimura and Tamura, 1988, 1991). In addition, some granulosa cells from the non-disc region showed mitotic features when studied using flow cytometry or $\left[{ }^{3} \mathrm{H}\right]$ thymidine incorporation in vitro (Marrone et al., 1990; Tilly et al., 1992). The reason why granulosa cells in the non-disc region proliferate in vitro but not in situ is uncertain. We assume that cell to cell communication is important in the regulation of cell proliferation in situ. The presence of gap junctions between granulosa cells and between granulosa cells and the oocyte suggests the presence of a mechanism for such cell to cell communication (Perry et al., 1978b; Yoshimura et al., 1993a).

The percentage of thecal cells in the F3 and F1 follicles labelled with BrdU $4 \mathrm{~h}$ before ovulation (after the preovulatory LH surge) was higher than $10 \mathrm{~h}$ before ovulation (before the LH surge). Overall, thecal cells were more extensively labelled with BrdU in F3 than in FI follicles. It therefore seems likely that the LH surge increases the proliferation of thecal cells. Unlike granulosa cells, there were no significant differences in the numbers of labelled cells between the germinal disc and non-disc regions of either F1 or F3 follicles. This observation suggests that the rate of proliferation of thecal cells changes during the development of follicles and during the ovulatory cycle. Factors originating from the oocyte and the germinal disc region may not play an important role in the proliferation of thecal cells. Our results also support the observation that mitosis of thecal cells is maintained during follicular growth but decreases during the final stage of maturation (Callebaut $e t$ al, 1990). Thecal tissue is a rich source of growth factors including epidermal growth factor and transforming growth factors $\alpha$ and $\beta$, and their production is greater in smaller follicles (Onagbesan et al., 1994; Law et al., 1995). It is possible that these growth factors are involved in the regulation of the proliferation of thecal cells.

In conclusion, we have confirmed that granulosa cells proliferate in both the germinal disc and non-disc regions in growing follicles, but granulosa cells in the germinal disc region continue to proliferate in the mature, FI follicle. The proliferation of thecal cells is greater in smaller follicles than in mature follicles, especially after the preovulatory LH surge.

This work was supported by grants from Kieikai Foundation (Tokyo, Japan 150) and Grants-in-Aid from Ministry of Education, Science and Culture of Japan (0660356) to Y. Yoshimura.

\section{References}

Bahr JM, Wang S-C, Haung MY and Calvo FO (1983) Steroid concentrations in isolated theca and granulosa layers of preovulatory follicles during the ovulatory cycle of the domestic hen Biology of Reproduction 29 326-334

Buccione R, Vanderhyden BC, Caron PJ and Eppig JJ (1990) FSH-induced expansion of the mouse cumulus oophorus in vitro is dependent upon a specific factor(s) secreted by the oocyte Developmental Biology 138 16-25

Callebaut M, Sijens RJ and Van Nassauw L (1990) Evolution of the avian ovarian follicle wall during its expansion European Archives of Biology 101 77-87

Calvo FO, Wang S-C and Bahr JM (1981) LH-stimulable adenylcyclase activity during the ovulatory cycle in granulosa cells of the three largest follicles and the postovulatory follicle of the domestic hen (Gallis domesticus) Biology of Reproduction $25805-812$ 
Doi O, Nakamura T and Tanabe Y (1980) Changes in the pituitary and plasma LH, plasma and follicular progesterone and estradiol, and plasma testosterone and estrone concentrations during the ovulatory cycle of the quail (Coturnix coturnix japonica) General and Comparative Endocrinoiogy 41 $156-163$

Gilbert AB, Hardie MA, Perry MM, Dick HR and Wells JM (1980) Cellular changes in the granulosa layer of the maturing ovarian follicle of the domestic fowl British Poultry Science 21 257-263

Jackson JA, Tischkau SA, Zhang P, Yoshimura Y and Bahr JM (1993) Involvement of plasminogen activator and collagenase and changes in extracellular matrix during the proliferative and ovulatory phases of the chicken ovary. In Avian Endocrinology pp 309-320 Ed. PJ Sharp. Journal of Endocrinology Ltd, Bristol

Law AS, Burt DW and Armstrong DG (1995) Expression of transforming growth factor- $\beta$ mRNA in chicken ovarian follicular tissue General and Comparative Endocrinology 98 227-233

Marrone BL, Jamaluddin M and Hertelendy F (1990) Regional pattern of cell maturation and progesterone biosynthesis in the avian granulosa cell layer Biology of Reproduction 42 405-412

Nitta H, Osawa Y and Bahr JM (1991) Immunolocalization of steroidogenic cells in small follicles of the chicken ovary: anatomical arrangement and location of steroidogenic cells change during follicular development Domestic Animal Endocrinology 8 587-594

Onagbesan OM, Gullick W, Woolveridge I and Peddie MJ (1994) Immunohistochemical localization of epidermal growth factor receptors, epidermalgrowth-factor-like and transforming growth-factor- $\alpha$-like peptides in chicken ovarian follicles Journal of Reproduction and Fertility 102 147-153

Palmer SS and Bahr JM (1989) Decreased number of small follicles and prolonged FSH responsiveness are associated with a reduced ovulation rate in aging chickens Biology of Reproduction 38 (Supplement 1) 184

Peddie MJ, Onagbesan OM and Williams J (1994) Chicken granulosa cell proliferation and progesterone production in culture: effects of EGF and theca secretions General and Comparative Endocrinology 94 341-356

Perry MM, Gilbert AB and Evans AJ (1978a) The structure of the germinal disc region of the hen's ovarian follicle during the rapid growth phase journal of Anatomy 127 379-392

Perry MM, Gilbert AB and Evans AJ (1978b) Electron microscope observations on the ovarian follicles of the domestic fowl during the rapid growth phase Journal of Anatomy 125 481-497
Soriano E and Del Rio JA (199I) Simultaneous immunocytochemical visualization of bromodeoxyuridine and neural tissue antigens Journal of Histochemistry and Cytochemistry 39 255-263

Tilly JL, Kowalski KI, Li Z, Levorse JM and Johnson AL (1992) Plasminogen activator activity and thymidine incorporation in avian granulosa cells during follicular development and the periovulatory period Biology of Reproduction 46 195-200

Vanderhyden BC, Caron PJ, Buccione R and Eppig JJ (1990) Developmental pattern of the secretion of cumulus expansion-enabling factor by mouse oocytes and the role of oocytes in promoting granulosa cell differentiation Developmental Biology 140 307-317

Vanderhyden BC, Telfer EE and Eppig IJ (1992) Mouse oocytes promote proliferation of granulosa cells from preantral and antral follicles in vitro Biology of Reproduction 46 1196-1204

Yoshimura Y and Bahr JM (1991) Localization of progesterone receptors in pre- and postovulatory follicles of the domestic hen Endocrinology 128 $323-330$

Yoshimura Y and Bahr JM (1995) Atretic changes of follicular wall caused by destruction of the germinal disc region of an immature preovulatory follicle in the chicken: an electron microscope study Journal of Reproduction and Fertility 105 147-151

Yoshimura $Y$ and Tamura T (1988) Effects of gonadotropins, steroid hormones, and epidermal growth factor on the in vitro proliferation of chicken granulosa cells Poultry Science 67 814-818

Yoshimura $Y$ and Tamura $T$ (1991) Cyclic adenosine monophosphate promotes the proliferation of chicken granulosa cells in culture General and Comparative Endocrinology 84 222-227

Yoshimura Y, Okamoto T and Tamura T (1993a) Electron microscope observations on $\mathrm{LH}$-induced oocyte maturation in Japanese quail (Coturnix coturnix japonica) Journal of Reproduction and Fertility 98 401-407

Yoshimura Y, Chang C, Okamoto T and Tamura T (1993b) Immunolocalization of androgen receptor in the small, preovulatory and postovulatory follicles of laying hens General and Comparative Endocrinology 91 81-89

Yoshimura Y, Tischkau SA and Bahr JM (1994) Destruction of the germinal disc region of an immature preovulatory follicle suppresses follicular maturation and ovulation Biology of Reproduction 51 229-233

Yoshimura Y, Okamoto T and Tamura T (1995) Changes in localization of ovarian immunoreactive estrogen receptor during follicular development in hens General and Comparative Endocrinology 100 368-374 